\title{
SEASONAL ABUNDACE OF RHINOCEROS BEETLES CAPTURED IN LIGHT TRAP AT KASSASSEN DISTRICT, ISMAILIA GOVERNORATE
}

\author{
EL-DEEB, M. A. ${ }^{1}$, M. M. EL-ZOHAIRY ${ }^{1}$, H. H. HASHEM ${ }^{2}$ AND OLFAT E. ARAFA ${ }^{2}$ \\ 1. Plant Protection Department, Faculty of Agriculture, Zagazig university \\ 2. Plant Protection Research Institute, ARC, Zagazig, Sharkia
}

(Manuscript received 13 October 2008)

\begin{abstract}
Seasonal abundance of Rhinoceros beetles, Oryctes spp. and Phyllognathus excavatus. were carried out under field conditions. Results obtained could be summarized as follows:-

1- Ecological studies on adult stage was carried out at kassassen district, the following results were obtained

* The seasonal abundance of adult stage was carried out by using light trap during seasons 1997, 1998 and 1999.

The activity period of Oryctes spp. was extended from March/ April until December in all investigated seasons the highest activity numbers during October (1300individuals). Two times of activities at September (1187 individuals) and October (1300 individuals) the highest number of insects was trapped during season of 1997 followed by 1998 while the least was at 1999 with densities 1668, 1443 and 1271 individuals respectively. Activity period of Ph. excavatus extended from January until December in all investigated seasons the highest activity was recorded during October (860 individuals).Another activity period was at August (410 individuals). The highest number of insects captured in light trap was recorded during season 1997 followed by 1998 and the least at 1999 with densities of 1249, 915 and 726 individuals, respectively. male sex ratio of Oryctes spp. was $60.17 \%$ in October, it increased to (65.76 \%)in September, while it was $58.81 \%$ for Phyllognathus excavatus in February but it increased to $60.85 \%$ in June. Simple correlation and partial regression values were positive and insignificant between Oryctes numbers and both minimum and maximum temperature where $r$ value ranged $(0.301-0.316$ and $0.225-0.289 \& b$ ranged $(4.889-4.609$ and $3.277-3.683)$ and E.v. \% ranged (51.41 - $25.44 \%$ and $32.73-69.55 \%$ ) in all investigated seasons except during 1999, values were positive and significant effects where $r$ ranged $(0.459 * *-0.490 * *)$, b ranged (4.096 - 4.381) and E.v. \% ranged (91.5 - 34.61 \%). While it was negative and insignificant for relative humidity, $r=(0.068,-0.116$ and -0.135$), b=(2.694,-2.247$ and -0.842$)$ and E.v. $\%=$ (54.31 - 22.77 and $5.71 \%)$.The explained variance percentage (E.v. \%) on the number of captured insects was about $14.66 \%$ for males while it was $21.93 \%$ for female. In case of Phyllognathus excavatus, had positive and highly significant effects both Minimum and Maximum temperature where $r$ value ranged $(0.385 * *$ $0.388 * *,-0.457 * *-0.525 * * *$ and $-0.526 * * *-0.466 * * \& b$ ranged $(0.057-0.067,0.119-0.163$ and $0.202-0.187)$ and E.v. \% ranged [19.1 - 12.25\%, $-83.9-23.24 \%$ and $18.3-(-45.4 \%)]$ on the numbers of captures in all investigated seasons. While it was negative and insignificant for relative humidity, $r=(-0.243$,
\end{abstract}


$0.372 *$ and 0.164$), \mathrm{b}=(-0.036,-0.062$ and 0.068$)$ and E.v. $\%=$ $(89.2,-4$ and $43.8 \%$ ). The explained variance percentage (E.v. \%) was about $22.6 \%$ for males, while it was $25.43 \%$ for females.

\section{INTRODUCTION}

Adults of black palm beetles Oryctes spp. Phyllognathus excavatus Forster and red palm weevil are large and widely distributed group of insects. In Egypt, first recorded in date palm plantations of Sharkia and Ismailia Governorates by Saleh (1993), Alfieri (1976) and Shalaby (1958) in the MOA collection, Plant Prot. Res. Institute.

Little work has been done on Oryctes spp. and Phyllognathus spp., special stress, however has been laid by Hafez and Bishara(1961) in Pentodon bispinosus, Mohammed and Ibrahim (1988) on Tropinota squalida, El-Deeb (1992 ) on T. squalida, Hammad and Ramadan (1979) on Oryctes elegans and Okil et al (2000) on Phyllognathus spp. Although various studies have been conducted on Oryctes spp. and Phyllognathus spp. in other countries by authors such as Cherian and Anantanaraynan(1939) , Fleming (1955), Williams et al (1955), Lohar and Mecci(1985) and Eitan (1993) .

Therefore, it was found expecdient that a detailed study on ecology of adults of Oryctes spp. and Phyllognathus spp. under field conditions in newly reclaimed areas at kassassen district, Ismailia Governorate is necessary.

\section{MATERIALS AND METHODS}

The experiments were carried out in field area of 80 feddans during three successive seasons, 1997, 1998and 1999 in a heavily infested zone with both fruit stalk beetles and red palm weevils.

\section{Seasonal abundance of rhinoceros beetles captured in light trap}

Monitoring of adults Oryctes spp.and Phyllognathus spp.were performed at Sabri village, Kassassen district, Ismailia Governorate. during the period extended from 1997 to 1999 .one light trap (Robinson light trap previously proposed by Williams (1923)) was placed on building at the height of 3 meters over areas of El- Kassassen district and fitted with a 200 watt ultraviolet lamp (Mercury - vapor lamp) it was operated daily from sunset to sunrise. Trap catch was weekly examined, identified, counted and sexed. 


\section{Effect of certain climatic factors on the insect population}

The prevailing means of air temperature $\left(\mathrm{C}^{\circ}\right)$, relative humidity (R.H. \%) were obtained from the central laboratory for Agriculture Meteorology, Agricultural Research Center, Ministry of Agriculture in Giza.

The simple and multiple correlation values ( $r$.) and partial regression values (b) and explained variance (E.v. \%) were calculated for relationship between the flight activity of counted adults and such weather factors.

Statistically analyzed using statistical program of costat. All the obtained data were statistically analyzed according to Duncans (1955) and little and Hills (1975).

\section{RESULTS AND DISCUSSION}

\section{Seasonal abundance of rhinoceros beetles captured in light trap}

\subsection{Oryctes spp}

The results presented in Table (1) revealed that the activity period of Oryctes spp. was extended from March /April until December in all investigated seasons with highest activity recorded during October (1300 individuals). Two times of activities, at September (1187 individuals) and October (1300 individuals). In Table (2) the highest trapped number of the insect was recoded in 1997 followed by 1998 and the least at 1999 with densities 1668, 1443 and 1271, respectively., while in Table (1)the percentage of sex ratio of males was $60.17 \%$ and it was increased gradually from the beginning of season and reached its maximum in September (65.76 \%). The total number of males was (2639), it was about 1.5 times more than females (1743). However, Eitan (1993) found that Oryctes agamemnon adult activity began in early May, peaks were during June - July and in September.

\subsubsection{Effect of weather factors}

The results obtained in Table (4) show that the simple correlation and partial regression values were positive and insignificant for both minimum and maximum temperature during 1997 and 1998 seasons. E.v. were $51.41 \%$ and $25.44 \%$ for mini.and max.temperature in 1997 respect. And $-32.73 \% \& 69.55 \%$ in 1998 .while in 1999, the previously mentioned factors had appositive and significant effects, where $r$ ranged $(0.490 * *-0.459 * *)$, b ranged $(4.096-4.381)$ and E.v. \% ranged $(91.5-34.61$ $\%)$.while the correlation was negative and insignificant for relative humidity , $r=r=$ $(0.068,-0.116$ and -0.135$), b=(2.694,-2.247$ and -0.842$)$ and E.v. $\%=(54.31-$ 22.77 and $5.71 \%$ ) in the three tested seasons,respectively. The explained variance percentage (E.v\%) on the number of captured insects was about $14.66 \%$ for males while it was $21.93 \%$ for females while El- Deeb (1992), mentioned that the correlation between flight activity of adults of $T$. squalida and both of day 
temperature and light intensity was positive and highly significant, While it was negative and highly significant with day relative humidity. The population increased gradually by increasing both temperature \& light intensity and by decreasing relative humidity. For example, the highest accumulated numbers on three hosts occurred at 2 p.m. with about 14.64 beetles / $\mathrm{m}^{2}$ and relative percentage, $19.09 \%$ during the highest degree of temperature $29^{\circ} \mathrm{C}$. and 82.000 lux light intensity, accompanied with the lowest relative humidity $54 \%$ R.H.

\subsection{Phyllognathus excavatus Forester}

Data in Table (1) reveal that the activity period of $P h$. excavatus extended from January until December in all investigated seasons with highest activity during October (860 individuals). Two times of activity were noticed during August (410 individuals) and October (860 individuals). in Table (2) the highest number captured insects by light trap was recorded during season 1997 (1249 individuals) followed by 1998(915 individuals) while the least was at 1999 with density of (726 individuals), while in Table (1) the general percentage of sex ratio of males was $58.81 \%$ throughout the all period of study of season until its maximum the highest percentage of males was in June (60.85\%).Okil et al (2000) found that the seasonal cycle of Ph. excavatus beetles consisted of an activity period lasted about $9.5-10.5$ months from March to late December or January of the next year, followed by an inactive period (1.5 - 2.5 months) during February, March and / or January. The accumulative total number of beetles emerged during the whole year round reached 446, 504 and 543 beetles at the end of December 1996, 1997 and 1998, respectively. Beetle infestation increased to 2.13 and 3.35 times during one and two years, respectively.

\subsubsection{Effect of weather factors}

Results of statistical analyses shown in Table (4) reveal that the simple correlation and partial regression values were positive and highly significant for both Minimum and Maximum temperature where $r$ values ranged $\left(0.388^{* *}-0.385 * *\right.$, $0.457^{* *}-0.525 * * *$ and $0.526 * * *-0.466 * * \& b$ ranged $(0.057-0.067,0.119-$ 0.163 and $0.202-0.187)$ and E.v. \% ranged [19.1 - $12.25 \%,-83.9-23.24 \%$ and $18.3-(-45.4 \%)]$ in 1997,1998 and 1999 seasons respectively . while it was negative and insignificant for relative humidity the explained variance percentage (E.v. $\%$ ) was about $22.6 \%$ for males, while it was $25.43 \%$ for females . Okil et al (2000) studied the direct effects (" $r$ " correlation values) of mean maximum and minimum temperature and relative humidity in new reclaimed lands (Giza governorate) on population activity of Ph. excavatus during study showed significantly positive effect with the maximum and minimum temperature, while the effect of maximum relative 
humidity was significantly negative. The combined effect of the tested weather factors on beetles activity in Giza was highly significant, where the calculated " $F$ " values were 4.32, 6.05 and 10.76 in 1996, 1997 and 1998 and \% explained variance were 47.6, 56.0 and 69.4 , respectively.

Table 1. Monthly average number of captured adults of Rhinoceros beetles Oryctes spp. and Phyllognathus excavatus cited at El-Gala farm, El- Kassassen district, Ismailia Governorate during three successive seasons, 1997, 1998 and 1999.

\begin{tabular}{|c|c|c|c|c|c|c|c|c|}
\hline & \multicolumn{4}{|c|}{ Oryctes spp. } & \multicolumn{3}{|c|}{ Phyllognathus excavatus } \\
\cline { 2 - 9 } Date & Male & Female & Total & $\begin{array}{c}\text { Sex ratio } \\
\% \text { of } \\
\text { males }\end{array}$ & Male & Female & Total & $\begin{array}{c}\text { Sex ratio } \\
\% \text { of } \\
\text { males }\end{array}$ \\
\hline Jan. & 0 & 0 & 0 & 0 & 1 & 1 & 2 & 16.66 \\
\hline Feb. & 0 & 0 & 0 & 0 & 46 & 32 & 78 & 58.81 \\
\hline March & 2 & 1 & 3 & 22.22 & 70 & 50 & 120 & 58.37 \\
\hline April & 104 & 74 & 178 & 58.81 & 109 & 95 & 204 & 53.51 \\
\hline May & 212 & 194 & 406 & 50.64 & 129 & 120 & 249 & 53.04 \\
\hline June & 236 & 185 & 421 & 56.73 & 137 & 88 & 225 & 60.85 \\
\hline July & 180 & 159 & 339 & 53.43 & 168 & 131 & 299 & 56.06 \\
\hline Aug. & 308 & 211 & 519 & 58.24 & 209 & 201 & 410 & 51.03 \\
\hline Sep. & 781 & 406 & 1187 & 65.76 & 187 & 191 & 378 & 49.34 \\
\hline Oct. & 799 & 501 & 1300 & 60.17 & 462 & 398 & 860 & 52.73 \\
\hline Nov. & 12 & 9 & 21 & 59.25 & 31 & 28 & 59 & 53.35 \\
\hline Dec. & 5 & 3 & 8 & 41.66 & 6 & 0 & 6 & 33.33 \\
\hline Total & 2639 & 1743 & 4382 & 60.22 & 1555 & 1335 & 2890 & 53.8 \\
\hline
\end{tabular}

Table 2. The total number of Oryctes spp. and Phyllognathus excavatus. Captured in light traps cited at El-Gala farm, El- Kassassen district, Ismailia Governorate during three successive seasons, 1997, 1998 and 1999.

\begin{tabular}{|c|c|c|}
\hline season & Oryctes spp & Phyllognathus excavatus \\
\hline 1997 & 1668 & 1249 \\
\hline 1998 & 1443 & 915 \\
\hline 199 & 1471 & 726 \\
\hline Total & 4382 & 2890 \\
\hline
\end{tabular}


Table 3. Monthly mean max., mini. Temp ${ }^{\circ} \mathrm{C}$ and R.H. \% at El-Gala farm, El-Kassassen district, Ismailia Governorate during three successive seasons, 1997, 1998 and 1999.

\begin{tabular}{|c|c|c|c|c|c|c|c|c|c|}
\hline & \multicolumn{3}{|c|}{1997} & \multicolumn{3}{|c|}{1998} & \multicolumn{3}{|c|}{1999} \\
\hline Date & $\begin{array}{c}\text { Max. } \\
\text { TempoC }\end{array}$ & $\begin{array}{l}\text { Mini. } \\
\text { Tempo C }\end{array}$ & $\begin{array}{l}\text { R.H. } \\
\%\end{array}$ & $\begin{array}{c}\text { Max. } \\
\text { Tempo C }\end{array}$ & $\begin{array}{c}\text { Mini. } \\
\text { TempoC }\end{array}$ & $\begin{array}{l}\text { R.H. } \\
\%\end{array}$ & $\begin{array}{l}\text { Max. } \\
\text { TempoC }\end{array}$ & $\begin{array}{l}\text { Mini. } \\
\text { Tempo C }\end{array}$ & $\begin{array}{l}\text { R.H. } \\
\%\end{array}$ \\
\hline January & 20.62 & 7.59 & 64.15 & 20.54 & 8.15 & 55.67 & 21.18 & 8.36 & 56.53 \\
\hline February & 20.56 & 8.08 & 65.21 & 21.83 & 9.38 & 56.60 & 23.83 & 9.60 & 55.35 \\
\hline March & 22.94 & 9.78 & 65.09 & 22.91 & 9.03 & 52.50 & 23.67 & 10.45 & 52.74 \\
\hline April & 27.05 & 12.99 & 60.82 & 29.15 & 12.84 & 49.88 & 27.67 & 12.82 & 48.62 \\
\hline May & 34.70 & 17.105 & 57.74 & 31.92 & 17.37 & 50.25 & 32.83 & 16.36 & 49.05 \\
\hline June & 35.09 & 20.245 & 58.48 & 34.50 & 19.84 & 49.57 & 35.57 & 21.33 & 52.46 \\
\hline July & 37.06 & 21.83 & 51.04 & 37.15 & 21.59 & 48.91 & 36.30 & 21.88 & 53.28 \\
\hline August & 37.89 & 23.48 & 52.12 & 39.05 & 23.94 & 51.03 & 37.62 & 23.56 & 51.43 \\
\hline September & 36.66 & 21.67 & 55.695 & 37.69 & 22.82 & 51.32 & 35.78 & 20.80 & 59.46 \\
\hline October & 33.22 & 18.16 & 55.72 & 33.80 & 18.33 & 51.88 & 33.03 & 18.80 & 62.57 \\
\hline November & 27.27 & 13.88 & 55.14 & 28.37 & 14.39 & 55.28 & 30.27 & 13.90 & 61.42 \\
\hline December & 22.46 & 9.26 & 56.45 & 23.65 & 11.19 & 54.28 & 23.55 & 9.18 & 63.08 \\
\hline
\end{tabular}

Max. Temp. ${ }^{\circ} \mathrm{C} .=$ maximum temperature.

Mini. Temp. ${ }^{\circ} \mathrm{C} .=$ minimum temperature.

R.H. \% = relative humidity percentage 
Table 4. Multiple \& simple correlation, partial regression and (E.v. \%) values between population of Oryctes spp and Phyllognathus excavatus and each of mini, max. Temp ${ }^{\circ} \mathrm{C}$ and mean of R.H. \%.at El- Gala farm, El- Kassassen district, Ismailia Governorate during 1997, 1998 and 1999.

\begin{tabular}{|c|c|c|c|c|c|}
\hline seasonal & \multicolumn{3}{|c|}{ Weather factors } & Oryctes spp. & Phyllognathus \\
\hline \multirow{9}{*}{1997} & \multirow{3}{*}{ Mini. Temp ${ }^{\circ} \mathrm{C}$} & $\begin{array}{c}\text { Simple } \\
\text { correlation }\end{array}$ & 20 & 0.301 & $0.388^{* *}$ \\
\hline & & $\begin{array}{l}\text { Partial } \\
\text { regression }\end{array}$ & b. & 4.889 & 0.057 \\
\hline & & E.v. $\%$ & $\mathrm{R}^{2} \times 100$ & $51.41 \%$ & $19.1 \%$ \\
\hline & \multirow{3}{*}{ Max. Tempo ${ }^{\circ} \mathrm{C}$} & $\begin{array}{c}\text { Simple } \\
\text { correlation }\end{array}$ & 20 & 0.316 & $0.385^{* *}$ \\
\hline & & $\begin{array}{l}\text { Partial } \\
\text { regression }\end{array}$ & b. & 4.609 & 0.067 \\
\hline & & E.v. $\%$ & $\mathrm{R}^{2} \times 100$ & $25.44 \%$ & $12.25 \%$ \\
\hline & \multirow{3}{*}{ Mean R.H. \% } & $\begin{array}{c}\text { Simple } \\
\text { correlation }\end{array}$ & 20 & 0.068 & -0.243 \\
\hline & & $\begin{array}{c}\text { Partial } \\
\text { regression }\end{array}$ & b. & 2.694 & -0.036 \\
\hline & & E.v. $\%$ & $\mathrm{R}^{2} \times 100$ & $54.31 \%$ & $89.2 \%$ \\
\hline \multirow{9}{*}{1998} & \multirow{3}{*}{ Mini. Temp ${ }^{\circ} \mathrm{C}$} & $\begin{array}{c}\text { Simple } \\
\text { correlation }\end{array}$ & 20 & 0.225 & $0.457 * *$ \\
\hline & & $\begin{array}{c}\text { Partial } \\
\text { regression }\end{array}$ & b. & 3.277 & 0.119 \\
\hline & & E.v. $\%$ & $\mathrm{R}^{2} \times 100$ & $-32.73 \%$ & $-83.9 \%$ \\
\hline & \multirow{3}{*}{ Max. Temp ${ }^{\circ} \mathrm{C}$} & $\begin{array}{c}\text { Simple } \\
\text { correlation }\end{array}$ & 20 & 0.289 & $0.525^{* * *}$ \\
\hline & & $\begin{array}{l}\text { Partial } \\
\text { regression }\end{array}$ & b. & 3.683 & 0.163 \\
\hline & & E.v.\% & $\mathrm{R}^{2} \times 100$ & $69.55 \%$ & $23.24 \%$ \\
\hline & \multirow{3}{*}{ Mean R.H. \% } & $\begin{array}{c}\text { Simple } \\
\text { correlation }\end{array}$ & 20 & -0.116 & $-0.372 *$ \\
\hline & & $\begin{array}{c}\text { Partial } \\
\text { regression }\end{array}$ & b. & -2.247 & -0.062 \\
\hline & & E.v. $\%$ & $\mathrm{R}^{2} \times 100$ & $22.77 \%$ & $-4 \%$ \\
\hline & Mini. Temp ${ }^{\circ} \mathrm{C}$ & $\begin{array}{c}\text { Simple } \\
\text { correlation }\end{array}$ & 20 & $0.459 * *$ & $0.526 * * *$ \\
\hline \multirow{8}{*}{1999} & & $\begin{array}{c}\text { Partial } \\
\text { regression }\end{array}$ & b. & 4.096 & 0.202 \\
\hline & & E.v. $\%$ & $\mathrm{R}^{2} \times 100$ & $91.5 \%$ & $18.3 \%$ \\
\hline & \multirow{3}{*}{ Max. Temp ${ }^{\circ} \mathrm{C}$} & $\begin{array}{c}\text { Simple } \\
\text { correlation }\end{array}$ & 20 & $0.490 * *$ & $0.46 * *$ \\
\hline & & $\begin{array}{c}\text { Partial } \\
\text { regression }\end{array}$ & b. & 4.381 & 0.187 \\
\hline & & E.v.\% & $\mathrm{R}^{2} \times 100$ & $34.61 \%$ & $-45.4 \%$ \\
\hline & \multirow{3}{*}{ Mean R.H. \% } & $\begin{array}{c}\text { Simple } \\
\text { correlation }\end{array}$ & 20 & -0.135 & 0.164 \\
\hline & & $\begin{array}{c}\text { Partial } \\
\text { regression }\end{array}$ & b. & -0.842 & 0.068 \\
\hline & & E.v. $\%$ & $\mathrm{R}^{2} \times 100$ & $5.71 \%$ & $43.8 \%$ \\
\hline \multirow{2}{*}{ Mean } & Male & & & $14.66 \%$ & $22.6 \%$ \\
\hline & Female & & & $21.93 \%$ & $25.43 \%$ \\
\hline
\end{tabular}




\section{REFERENCES}

1. Alfieri, A. 1976. The Coleoptera of Egypt. Bull. Soc. Ent. Egypt, 5: 217.

2. Cherian, M. C. and K. P. Anantanarayanan. 1939. Studies on the coconut palm beetle (Oryctes rhinoceros Linn.) in South India. Indian J. Agric. Sci. ,3 (9): 541 559.

3. Duncan, S., D. B. 1955. Multiple range and multiple F. tests. (Biometrics, $11: 1$ 41).

4. Eitan, A. 1993. Oryctes agamemnon, a pest of date palms and lawns in the Arava valley. Hassadeh, 73 (5): $550-551$.

5. El-Deeb, M. A. 1992a. Biological and ecological studies on Tropinota squalida Scop. at Sharkia Governorate. I- the adult stage Zagazig J. Agric. Res., 19 (3): $1409-1419$.

6. Fleming, W. E. 1955. Controlling the Japanes beetle (U.S. Dept. Agr., Farmer's Bull., 2004.

7. Hafez, M. and S. I. Bishara. 1961 a. Studies on the biology and ecology of Pentodon bispinosus (Kust.) in Egypt. I - the adult stage (Coleoptera: Scarabaeidae: Dynastinae). (with 2 text figures) Bull. Soc. Ent. Egypt, xlv: 155 177.

8. Hammad, S. M. and M. M. Ramadan. 1979. Preliminary studies on the population density of some moths at Al-Hassa region using a light trap. Proc. Saudi Biol. Soc. (3): $79-100$.

9. Littel, T. M. and F. J. Hills. 1975. Text book of statistical methods in Agricultural research available from V.C.D. Book stor of California, Univ.

10. Lohar, M. K. and A. K. Mecci. 1985. Occurrence and habits of scarab beetles. Pakistan Journal of Agricultural Research, 6 (1): 49 - 54.

11. Mohamed, A. A. and I. L. Ibrahim. 1988. Preliminary study on occurrence and abundance of Tropinota squalida Scop. (Coleoptera: Scarabaeidae) infesting certain ornamental plants and fruit crops. Al-Azhar J. Agric. Res., 9: 1 - 15. 
12. Okil, A. M., S. M. Haggag and A. W. Tadros. 2000. Population dynamics of Phyllognathus excavatus Forster (Coleoptera: Scarabaeidae) in date palm orchards in Egypt. Annals of Agric. Sc., Moshtohor. 38 (2): 1307 - 1318.

13. Saleh M. R. A. 1993. Red palm weevil Rhynchophorous ferrugineus (Olivier) is the first recorded for Egypt and indeed the African continent .Lest on 10634 Africa , collection No.22563 Institute of Entomology 56 Queens Gate,London ,SW 75 $\mathrm{JR}, \mathrm{UK}$.

14. Shalaby, F. 1958. Alphabetical list of Egyptian insects in the collection of MOA. Tech. Bull., $135-284$.

15. Williams, C. B. 1923. A new type of light - trap for insects. Bull. 28, Tech. and Scientific service, Ministry of Agriculture, Cairo. C.F. Rev. App. Ent., (1973) 61 (11): 1130 .

16. Williams, B. et al. 1955. A second experiment on testing the relative efficiency of insects traps (Bull. Ent. Res., (London), xlvi: 193 - 204. 


\section{الوفرة الموسمية لخنافس الجعال المصادة بالمصيدة الضوئية بمنطقة القصاصين محافظة الإسماعيلية}

محمد على الايب' ، منصور محمد الزهيرى' ، حليم حسن هاشم ، القت السيد عرفة'

$$
\begin{aligned}
& \text { 1- قسم وقاية النبات - كلية الزراعة - جامعة الزقازيق } \\
& \text { r- معهُ بحوث وقاية النباتات - مركز البخوث الزراعية - الزقازيق -الثرقية }
\end{aligned}
$$

تمت هذة الدراسات بمزرعة الجلا بمنطقة القصاصين محافظة الإسماعيلية خلال مواسم نواجد

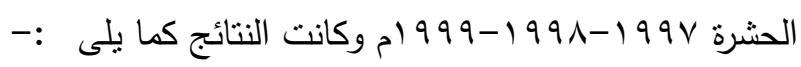

1- قياس التقلبـات الموسـمية لحشرتي. Phyllognathus excavatus and Oryctes باستخدام المصائد الضوئية:-

بدأ ظهور الحشرة الكاملة لل Oryctes spp المصادة بالمصائد الضوئية خلال مارس /ابريل

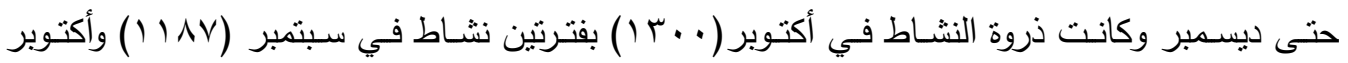

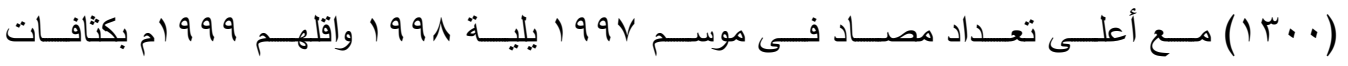

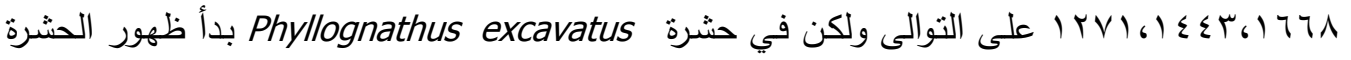

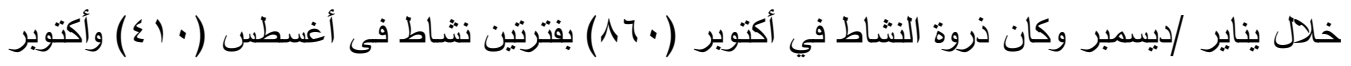

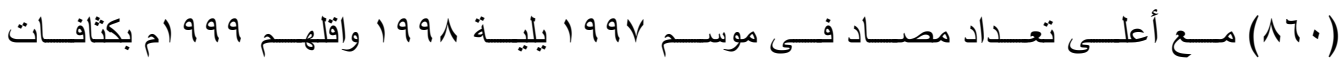

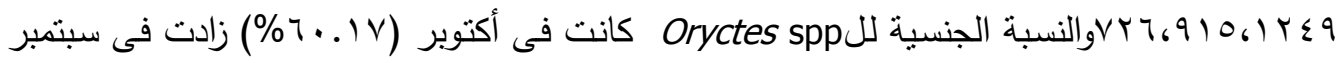

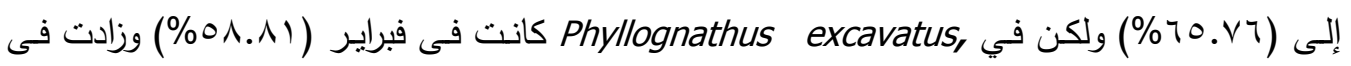

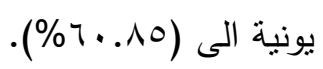

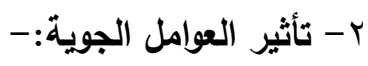

لحشرة Oryctes spp موجب وغير معنوي لكلا من درجتي الحرارة الصغربو العظمى حيث

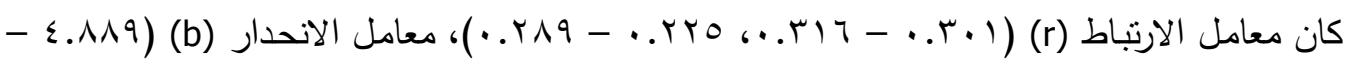

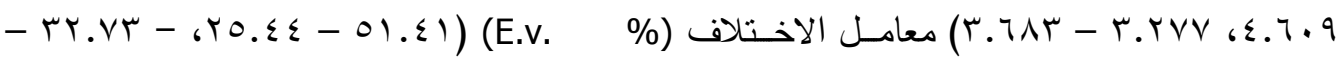

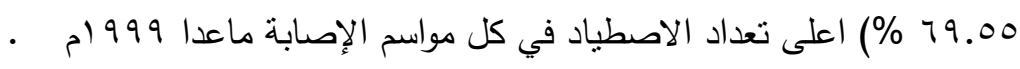

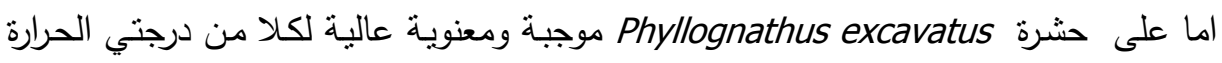

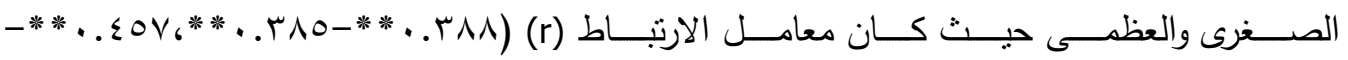

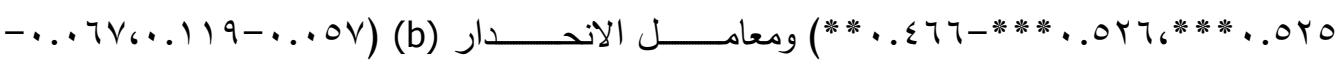

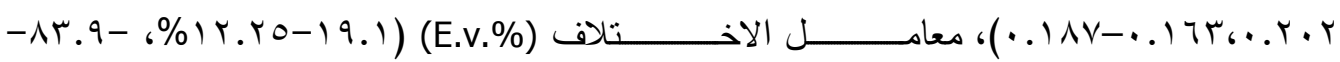
§. 

630 Egypt. J. Agric. Res., 87 (3), 2009 